\title{
AN OPIAL-TYPE INEQUALITY FOR FRACTIONAL DERIVATIVES OF TWO FUNCTIONS
}

\author{
M. ANDRIĆ, J. PEČARIĆ AND I. PERIĆ
}

Abstract. This paper presents improvements of some Opial-type inequalities involving the RiemannLiouville, Caputo and Canavati fractional derivatives, and presents some new Opial-type inequalities.

Mathematics subject classification (2010): 26A33, 26D15.

Keywords and phrases: Riemann-Liouville fractional derivative; Caputo fractional derivative; Canavati fractional derivative; Opial inequality.

\section{REFERENCES}

[1] R. P. Agarwal and P. Y. H. Pang, Opial Inequalities with Applications in Differential and Difference Equations, Kluwer Academic Publishers, Dordrecht, Boston, London (1995).

[2] R. P. Agarwal And P. Y. H. PANG, Sharp Opial-type inequalities involving higher order derivatives of two functions , Math. Nachr., 174 (1995), 5-20.

[3] H. Alzer, An Opial-type inequality involving higher-order derivativess ot two functions, Appl. Math. Lett., 10 (4) (1997), 123-128.

[4] G. A. Anastassiou, Fractional Differentiation Inequalities, Springer (2009).

[5] M. ANDRIĆ, J. PEČARIĆ AND I. PERIĆ, Improvements of composition rule for the Canavati fractional derivatives and applications to Opial-type inequalities, Dynam. Systems. Appl., 20 (2011), 383-394.

[6] M. Andrić, J. PeČArić And I. Perić, Composition identities for the Caputo fractional derivatives and applications to Opial-type inequalities, Math. Inequal. Appl., (2013), to appear.

[7] M. Andrić, J. PEČARIĆ And I. PERIĆ, A multiple Opial type inequality for the Riemann-Liouville fractional derivatives, J. Math. Inequal., 7 (1) (2013), 139-150.

[8] J. A. Canavati, The Riemann-Liouville integral, Nieuw Archief Voor Wiskunde, 5 (1) (1987), 53-75.

[9] A. A. Kilbas, H. M. SRivastava and J. J. Trujillo, Theory and Applications of Fractional Differential Equations, North-Holland Mathematics Studies 204, Elsevier (2006).

[10] S. G. Samko, A. A. Kilbas And O. I. Marichev, Fractional Integrals and Derivatives. Theory and Applications, Gordon and Breach, Reading (1993). 